\title{
A nátrium-glutamát génexpresszióra gyakorolt hatásainak vizsgálata
}

\author{
Jurasek Júlia Vanda ${ }^{1}$ - Raposa László Bence ${ }^{1}$ \\ Gubicskóné dr. Kisbenedek Andrea ${ }^{1}$. Varga Veronika ${ }^{2}$ \\ Szabó Zoltán ${ }^{1}$ - Varjas Tímea dr. ${ }^{3}$
}

Pécsi Tudományegyetem, Egészségtudományi Kar, 'Táplálkozástudományi és Dietetikai Intézet,

${ }^{2}$ Fizioterápiás és Sporttudományi Intézet, Pécs

${ }^{3}$ Pécsi Tudományegyetem, Általános Orvostudományi Kar, Orvosi Népegészségtani Intézet, Pécs

\begin{abstract}
Bevezetés: Napjainkban az élelmiszeripar egyre gyakrabban alkalmaz különféle adalékanyagokat az élelmiszerek előállítása során. Célkitüzés: Állatkísérletben vizsgáltuk, hogy a nátrium-glutamát tartós fogyasztása befolyásolja-e a DNSmetil-transzferázok génexpressziós mintázatát mRNS-szinten. Anyagok és módszer: Vizsgálatunkban 24 nőstény CD1 egeret kezeltünk különböző dózisú nátrium-glutamáttal. Az állatok máj-, vese-, tüdő- és lépszövetéből mintavételt követően kvantitatív RT-PCR segítségével határoztuk meg a DNMT1, DNMT3a és DNMT3b enzimeket kódoló gének expresszióját. Eredmények: A négy szövettípus génexpressziós mintázatában több esetben eltérést találtunk a kontrollcsoporthoz viszonyítva. A DNMTl mind a három csoportban szignifikánsan $(\mathrm{p}<0,05)$ visszaszorította a génexpressziót. A DNMT3A a tüdőszövetben az első és második csoportnál ( $\mathrm{p}<0,05)$, a vese- és májszövetben mind a három csoportnál szignifikánsan visszaszorította a génexpressziót $(\mathrm{p}<0,05)$. Köpetkeztetések: A nátrium-glutamát hasonlóan a kemopreventív tulajdonságokkal rendelkező epigallo-katekin-galláthoz, kurkuminhez, geniszteinhez, likopinhoz, rezveratrolhoz, mRNS-szinten visszaszorította a kísérleti egerek több szervében is a DNMT1 és DNMT3A génexpresszióját, amely tulajdonságai miatt feltételezhető, hogy antikarcinogén hatással is rendelkezik.Orv. Hetil., $2017,158(10), 380-385$.
\end{abstract}

Kulcsszavak: élelmiszer-adalékanyag, nátrium-glutamát, génexpresszió, DNMTI, DNMT3a, DNMT3b

\section{Effects of dietary monosodium-glutamate on gene expression}

Introduction: Nowadays, the food industry more often uses different type of additives during the food production. Aim: Our aim was to examine the monosodium-glutamate's effect (in animal experiment) on DNA-methyltransferases in gene expression patterns of mRNA levels. Materials and method: In the investigation we used $24(\mathrm{n}=24) \mathrm{CD} 1$ type female mice. The animals were fed with different equivalent human doses of the tested substance. After autopsy, mRNA was isolated from different tissues (lung, liver, kidney, spleen). DNMT1, DNMT3A and DNMT3B levels were determined by Quantitative Real-Time PCR. Results: DNMTI significantly suppressed the gene expression in all the three treated groups $(\mathrm{p}<0.05)$. The DNMT3A expression patterns showed significant decreasing tendency in the 1 . and 2. treated groups of the lung tissue $(\mathrm{p}<0,05)$ and $1,2,3$. groups of liver and kidney tissues $(\mathrm{p}<0,05)$. Conclusions: Our results shows that the monosodium glutamate, suppressed the DNMTI and DNMT3A gene expression - on mRNA levels of several organs - in mice. It can be a similar chemopreventive effect to epigallo-catechin-gallate's, curcumin's, genistein's, likopine's and rezveratrol's effects. In this case it can be possible that the MSG has anticarcinogenic effects.

Keywords: food additive, monosodium-glutamate, gene expression, DNA-methyltransferase 1, DNA-methyltransferase $3 a, D N A$-methyltransferase $3 b$

Jurasek, J. V., Raposa, L. B., G. Kisbenedek, A., Varga, V., Szabó, Z., Varjas, T. [Effects of dietary monosodium-glutamate on gene expression]. Orv. Hetil., 2017, 158(10), 380-385.

(Beérkezett: 2016. november 27.; elfogadva: 2016. december 28.) 


\section{Rövidítések}

5Aza-C $=5$-azacytidine $; \mathrm{ADI}=($ acceptable daily intake $)$ napi megengedett beviteli mennyiség; $\mathrm{DMBA}=7,12$-dimethylbenz[a]anthracén; DNMT = DNS-metil-transzferáz; DNMT1 = DNS-metil-transzferáz-1; DNMT3a = DNS-metil-transzferáz-3a; DNMT3b = DNS-metil-transzferáz-3b; EGCG = epigallo-katekin-gallát; HDACl = hiszton-deacetiláz-1; MBD2 = methyl-CpG-binding domain protein $2 ; \mathrm{MSG}=$ (monosodium-glutamate) nátrium-glutamát; $\mathrm{NMBA}=\mathrm{N}$-nitrozómetilbenzilamin; RT-PCR = real-time polymerase chain reaction

Az emberiség már ősidők óta használ különféle adalékanyagokat az élelmiszerek minőségének megőrzése vagy javítása, a szín, íz és a textúra megváltoztatása céljából. Napjainkban az élelmiszerek előállítása során egyre gyakrabban alkalmaznak mind szintetikus, mind természetes forrásból előállított adalékanyagokat. Az élelmiszer-adalékanyagok szándékos hozzáadás révén kerülnek bele az élelmiszerekbe, azok érzékszervi tulajdonságainak javítása, eltarthatóságának növelése, tápértékének megőrzése, feldolgozhatóságának megkönnyítése céljából [1].

Az utóbbi években megjelent tanulmányok néhány mai napig alkalmazott - adalékanyag egészségkárosító hatásáról számolnak be. El-Wahab és Moram állatkísérletében az élelmiszer-színezékek közül a brilliantkék, azorubin, tartrazin, az ízesítőanyagok közül a transzanetol, propilén-glikol és a vanillin hatását vizsgálták. Az adalékanyagok szignifikánsan csökkentették a testtömeget, a hemoglobinkoncentrációt, vörösvérsejtszámot, valamint a vérben és a májban is szignifikánsan csökkentették a glutation-S-transzferáz-, szuperoxid-dizmutázaktivitást. Továbbá a kontrollcsoporthoz viszonyítva növekedett a szérum-alanin-amino-transzferáz-, aszpartát-amino-transzferáz-, alkalin-foszfatáz-aktivitás, valamint a bilirubin-, karbamid-, kreatin-, összprotein- és albuminszint [2].

Tsuda és mtsai a szintetikus vörös élelmiszer-színezékeket (amaranth, alluravörös, neukokcin) vizsgálták állatkísérletben. Kezelés után három, hat és 24 órával mintát vettek az agyból, tüdőből, májból, veséből, gyomorból, vastagbélből, húgyhólyagból. Alkalikus comet assay-vel történő elemzés során három órával a színezékek (amaranth, alluravörös) elfogyasztása után DNS-károsodást találtak a vastagbélben, hat órával az amaranthkezelést követően pedig a tüdőben. A neukokcin, amaranth és alluravörös együttesen a vastagbélben okozott DNS-károsodást, míg a neukokcin magában: a gyomor, vastagbél és a húgyhólyag esetén fejtett ki direkt degradációt [3].

Shah és Verma állatkísérletében bizonyította, hogy a butil-parabén indukálta oxidatív stressz központi szerepet játszik a hepatotoxicitásban. A kísérleti állatoknak (rágcsálók) 30 napon keresztül, három különböző dózisban adtak butil-parabént $(40,20$ és $13,33 \mathrm{mg} / 0,2 \mathrm{ml}$ olivaolaj/ttkg/nap), amely jelentős lipidperoxidáció-növekedést eredményezett. Biokémiai vizsgálatok szignifikáns $(\mathrm{p}<0,05)$ és dózisfüggő csökkenést eredményeztek a nem enzimatikus antioxidáns (például a glutation- és aszkorbinsavszintben), valamint szignifikáns csökkenést találtak az enzimatikus antioxidáns (például a szuperoxid-dizmutáz, kataláz, glutation-peroxidáz, glutationS-transzferáz) -szintek esetében is [4].

Eweka a nátrium-glutamát hisztokémiai hatásait vizsgálta felnőtt Wistar patkányok máján. A májszöveteket etanolba dehidratálták, xilinnel megtisztították és paraffinba ágyazták, majd forgó mikrotóm segítségével 7 mikron vastagságú metszeteket készítették. A deparaffinált metszeteket PAS-reagenssel kezelték. Digitális kutatási fényképészeti mikroszkóppal fotomikrográfos mintát kaptak. A nátrium-glutamáttal kezelt állatok mája több esetben jelentős szöveti eltérést mutatott. A centrális vénák szétesett vörösvérsejteket tartalmaztak, továbbá sejtszerkezeti torzulások voltak megfigyelhetők a májsejtekben. Egyes esetekben centrolobularis vérzéses nekrózisokat is megfigyeltek. A $0,08 \mathrm{mg} / \mathrm{ttkg}$ nátrium-glutamáttal kezelt csoportban atrófiás és degeneratív változások jelentek meg [5].

Az előbb említett vegyületek metabolizmusa és kiválasztása jelentősen függ a máj, a vese és a gastrointestinalis traktus állapotától. A károsodás veszélyének leginkább ezek a szervek vannak kitéve. Az élelmiszerek feldolgozása során alkalmazott különböző adalékanyagok együttesen a szervezetbe kerülve növelhetik a daganatképződés kockázatát $[6,7]$.

Az izfokozó anyagoknak önmagukban jelentéktelen íze és illata van, de már kis mennyiségben alkalmazva is sokszorosan felerősítik az élelmiszerek jellegzetes ízét, aromáját [8]. Az ízfokozó hatás és a kémiai szerkezet között szoros összefüggés van. Legismertebb vegyületek a glutaminsav és sói (INS 620, 621, 622), inozinsav és sói (INS 630, 632, 633, 631), valamint a guanilsav és sói (INS 626, 627, 628, 629). A munkacsoportunk által vizsgált nátrium-glutamát egy nem esszenciális aminosav, a glutaminsav sója, amely jelen van számos élelmiszerben. A nátrium-glutamát természetes módon megtalálható a parmezán sajtban, tehén- és anyatejben, csirke-, kacsahúsban, tojásban, sertés- és marhahúsban, makrélában, tőkehalban, tonhalban, hüvelyesekben, kukoricában, répában, spenótban, paradicsomban, burgonyában. A szabad glutamát szint az állati és növényi eredetű élelmiszerekben alacsony. Jelentősebb mennyiségben található meg füszerekben, szószokban, közétkeztetésben elkészített ételekben, a kereskedelemben található félkész-kész termékek többségében [9]. Napi ajánlott beviteli mennyisége (ADI) nincs meghatározva [10].

A karcinogenezis bizonyos lépései szorosan összefüggnek a hierarchikus és szabályozott génexpressziós mintázatokkal. A génexpressziót számos molekuláris folyamat szabályozza. Ezen folyamatok közül a DNSmetiláció egy epigenetikus folyamat, amely hosszú távú elfojtást, gátlást okoz a génexpressziós mintázatban. A DNS-metilációt a DNS-metil-transzferáz enzimcsalád (DNMT1, DNMT3a és DNMT3b) katalizálja. A DNSmetilációs minták a daganatos sejtekben nagymértékben 
módosulnak, így jelentős szerepük van a daganatos sejtek és az egészséges szövetek egymástól való megkülönböztetésében. A DNS-metil-transzferázok mindemellett létfontosságúak az embriogenezis során. Szerepük van a génexpresszió szabályozásában, az X-kromoszóma-inaktivációban, génátíródásban, kromatinmodifikációban és az endogén retrovírusok elcsendesítésében („silencing”) $[11,12]$.

A DNMT1-expresszió a sejtciklusban egy szigorúan szabályozott folyamat, amely képes „de novo” metilációra (új metilációs mintázat kialakítása). A DNMT3a legalább két enzimatikusan aktív fehérjeterméket kódol. A DNMT3b gén két aktív és három inaktív izoformát kódol. A DNMT3a és a DNMT3b alapvető fontosságú a de novo metilációban és az embrionális fejlődésben egyaránt $[13,14]$.

A de novo metiláció egy kritikus fejlődési folyamat az egerek fejlődésében, amelynek során a DNMT3b kiesése halálos kimenetelü az állatok embrionális állapotában. A tumorszuppresszor gének hipermetilációja allélvesztéssel járó inaktivációt és facilitált génmutációt okozhat [15]. Humán karcinogenezis esetében mindhárom DNS-metil-transzferáz emelkedett mRNS- és fehérjeexpressziós szintje a jellemző. A tumorszuppresszor gének hipermetilációja korrelál a DNS-metil-transzferázok magas expressziójával. Feltételezések szerint a tumoros elváltozások kialakulását az enzimek túltermelődése előzheti meg. A DNMT3a-ban előforduló káros mutációk okozta daganatok nem gyakoriak. Állatkísérletekben kimutatták, hogy a DNMTI-ben bekövetkező heterozigóta mutációk a DNS-metiláció csökkenését okozhatják, és csökkentik az intestinalis tumorok fejlődését, mindemellett növelhetik a lymphomagenesis kockázatát [16, 17]. Tüdődaganatos rágcsálómodellben ugyanakkor a DNMT3a törlése elősegítette a tumor progresszióját [18].

\section{Anyagok és módszer}

Vizsgálatunkban karcinogenezisre érzékeny egértörzsön (CDl) vizsgáltuk, hogy a nátrium-glutamát tartós fogyasztása mRNS-szinten befolyásolja-e az epigenetikai változásokban szerepet játszó DNS-metil-transzferázok génexpressziós mintázatát a kísérleti állatok különböző szerveiben.

Csoportonként hat-hat darab, hathetes $(\mathrm{m}=18 \pm$ $1,23 \mathrm{~g}$ ) nőstény CDl egeret alkalmaztunk. Az expozíció meghatározásánál Ataseven és mtsai korábbi vizsgálatának adatait vettük figyelembe, amely alapján a kísérleti állatok egyszeres, kétszeres és négyszeres humán ekvivalens dózist fogyasztottak 30 napon át [19]. A vizsgálat teljes ideje alatt a kontrollcsoport állatai szokványos rágcsálótápot, míg a kezelt egyedek speciális tápot fogyasztottak. A csoportfelosztást és a dózisokat az 1. táblázat tartalmazza.

A vizsgálatba bevont egereket a 30 . napon cervicalis dislocatiót követően felboncoltuk, szerveiket (vese, máj, lép, tüdő) kiemeltük, RNA-ase-mentes vízzel mostuk, totál RNS-t izoláltunk belőle Trizol-protokoll szerint (Nucleotest Bio Kft.). A génexpressziós mintázatot kvantitatív real time PCR-rel (ROSCHE Light Cycler 480) határoztuk meg, amelyhez a primereket a Primer Express $^{\mathrm{TM}}$ szoftverrel (Applied Biosystems) terveztük, és a Csertex Kft. szintetizáltatta (2. táblázat). A PCR-reakció $20 \mu \mathrm{l}$ végtérfogatban zajlott, a reakcióelegy mindkét primerból 200-200 nmol-t, $100 \mathrm{ng}$ RNS-t, $200 \mu \mathrm{g}$ dUTP-t, valamint egyszeres hígítású KAPA SYBR ${ }^{\circledR}$ FAST qPCR Master Mixet (Nucleotest Bio Kft.) és egyszeres hígítású KAPA RT Mixet (Nucleotest Bio Kft.) tartalmazott. A hőprogramot a KAPA SYBR ${ }^{\circledR}$ FAST One-Step qRT-PCR kit protokolljának megfelelően állítottuk be, az annealing hömérséklet $60{ }^{\circ} \mathrm{C}$ volt. Adatainkat IBM SPSS 21.0 statisztikai szoftverrel dolgoztuk fel. A változók összehasonlító elemzésére kétmintás t-próbát és varianciaanalízist alkalmaztunk. A szignifikanciaszintet p<0,05-nál határoztuk meg, 95\%-os konfidenciaintervallum mellett.

1. táblázat |A kezelésre felhasznált nátrium-glutamát dózisai

\begin{tabular}{ll}
\hline I. csoport & $700 \mathrm{mg} / \mathrm{ttkg}$ nátrium-glutamát/nap \\
II. csoport & $350 \mathrm{mg} / \mathrm{ttkg}$ nátrium-glutamát/nap \\
III. csoport & $175 \mathrm{mg} / \mathrm{ttkg}$ nátrium-glutamát/nap \\
Kontrollcsoport & $0 \mathrm{mg} / \mathrm{ttkg}$ nátrium-glutamát/nap \\
\hline
\end{tabular}

2. táblázat |A Q-RT-PCR során alkalmazott primer szekvenciák

\begin{tabular}{|c|c|c|}
\hline Gén neve & Primer kódja & Primer szekvenciája \\
\hline \multirow{2}{*}{$\begin{array}{l}\text { DNS-metil- } \\
\text { transzferáz-1 }\end{array}$} & DNMT1_F & AAGAATGGTGTTGTCTACCGAC \\
\hline & DNMT1_R & CATCCAGGTTGCTCCCCTTG \\
\hline \multirow{2}{*}{$\begin{array}{l}\text { DNS-metil- } \\
\text { transzferáz-3a }\end{array}$} & DNMT3A_F & GAGGGAACTGAGACCCCAC \\
\hline & DNMT3A_R & CTGGAAGGTGAGTCTTGGCA \\
\hline \multirow{2}{*}{$\begin{array}{l}\text { DNS-metil- } \\
\text { transzferáz-3b }\end{array}$} & DNMT3B_F & AGCGGGTATGAGGAGTGCAT \\
\hline & DNMT3B_R & GGGAGCATCCTTCGTGTCTG \\
\hline \multirow{2}{*}{$\begin{array}{l}\text { Hipoxantin- } \\
\text { foszforibozil- } \\
\text { transzferáz-1 }\end{array}$} & HPRT_F & TCAGTCAACGGGGGACATAAA \\
\hline & HPRT_R & GGGGCTGTACTGCTTAACCAG \\
\hline
\end{tabular}

\section{Eredmények}

A nátrium-glutamát fogyasztásának hatására bekövetkező génexpressziós mintázatok módosulását a bevezetésben ismertetett DNS-metil-transzferázok esetében mutatjuk be. A kísérleti állatok tüdejéből izolált mRNS génexpressziós mintázatában (1. ábra) a DNS-metiltranszferáz-1 enzimet kódoló génről expresszált mRNSszint a kontrollcsoportnál a legnagyobb, és már a legalacsonyabb dózisban fogyasztott nátrium-glutamát is visszaszorította a génexpressziót (0,53-szorosára). A magasabb dózisban fogyasztott nátrium-glutamát még ala- 
Tüdő

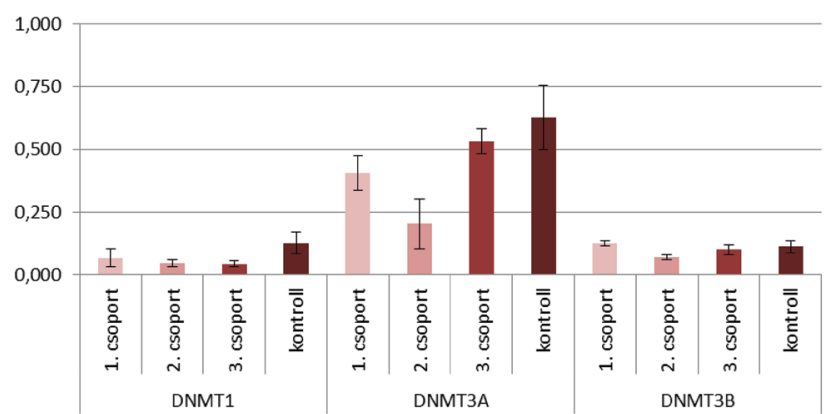

1. ábra

A DNS-metil-transzferázok expressziós mintázatának alakulása mRNS-szinten a kísérleti egerek tüdőszövetében

Vese

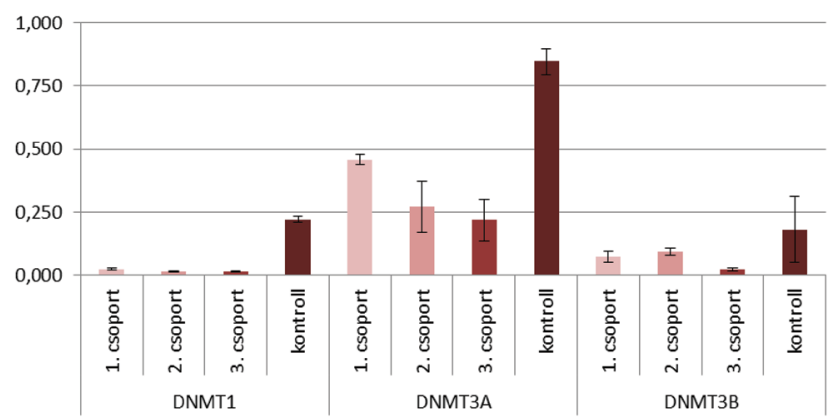

2. ábra

A DNS-metil-transzferázok expressziós mintázatának alakulása mRNS-szinten a kísérleti egerek veséjének szövetében

csonyabb mRNS-szintet eredményezett, amely különbségek szignifikánsak $(\mathrm{p}<0,05)$ voltak. A DNMT3a génexpressziós mintázata alapján megállapíthatjuk, hogy szignifikáns különbséget a kontrollcsoport értékeihez képest csak a második kezelt csoport egyedeinek tüdőszövetében mért mRNS-szintekben találtunk $(p<0,05)$. A DNS-metil-transzferáz-3b enzimet kódoló gén expressziós adatai szerint a nátrium-glutamát fogyasztás nem okozott szignifikáns változást $(\mathrm{p}<0,05)$.

A veseszövet mintázatában (2. ábra) a DNS-metiltranszferáz-1 és a DNS-metil-transzferáz-3a enzimet kódoló génekról expresszált mRNS koncentrációja a kontrollcsoportnál a legnagyobb, és mind a három különböző dózisban fogyasztott nátrium-glutamát szignifikánsan visszaszorította a génexpressziót a kísérleti egerek veseszövetében $(\mathrm{p}<0,05)$. A DNMT3b génexpressziós mintázata alapján megállapíthatjuk, hogy szignifikáns különbséget a kontrollcsoport értékeihez képest csak a harmadik csoport, a legalacsonyabb dózissal kezelt egyedeknek veseszövetében mért mRNS-szintekben találtunk $(\mathrm{p}<0,05)$.

Májszövet esetén (3. ábra) a DNMTl és a DNMT3a enzimet kódoló génekról expresszált mRNS-szint mind a három dózis hatására szignifikánsan visszaesett a kontrollcsoporthoz viszonyítva $(\mathrm{p}<0,05)$. A DNMT3b enzimet kódoló gén expressziós adatai szerint szintén nem

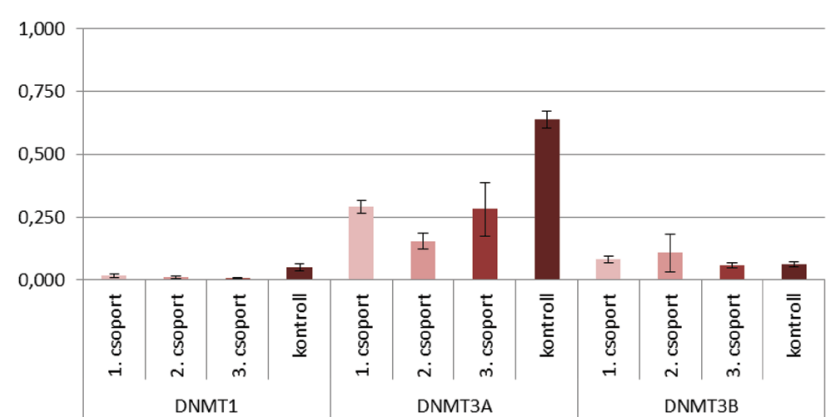

3. ábra $\quad$ A DNS-metil-transzferázok expressziós mintázatának alakulása mRNS-szinten a kísérleti egerek májszövetében

Lép

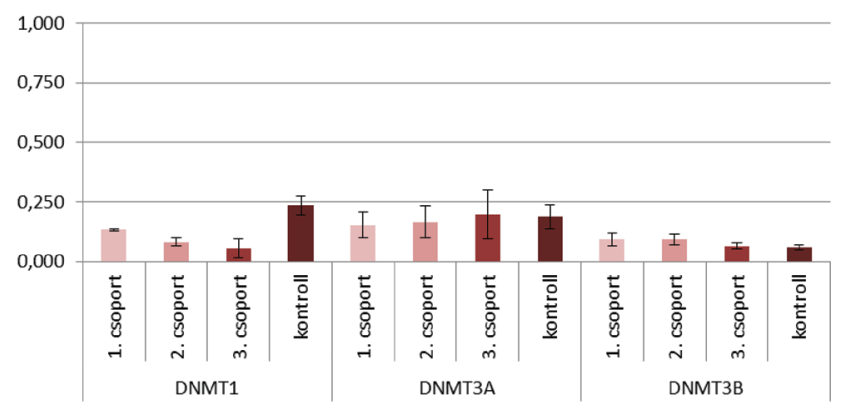

4. ábra $\quad$ A DNS-metil-transzferázok expressziós mintázatának alakulása mRNS-szinten a kísérleti egerek lépének szövetében

okozott szignifikáns változást a nátrium-glutamát-fogyasztás $(\mathrm{p}<0,05)$.

A lépszövet mintázatában (4. ábra) a DNS-metiltranszferáz-1 enzimet kódoló génről expresszált mRNS alapján megállapíthatjuk, hogy a nátrium-glutamát szignifikánsan csökkentette a génexpressziót mind a három kezelt csoport esetében a kontrollcsoporthoz képest $(\mathrm{p}<0,05)$. A DNS-metil-transzferáz-3a és - $3 \mathrm{~b}$ enzimet kódoló gének expressziós szintjei szerint nem okozott szignifikáns változást a nátrium-glutamát fogyasztás $(\mathrm{p}>0,05)$.

\section{Megbeszélés}

Vizsgálatunk során Ataseven és mtsai kísérletében alkalmazott nátrium-glutamát-dózis alapján történő fogyasztást modelleztük állatkísérletes tesztrendszerben [19]. A kísérlet 30. napján cervicalis dislocatiót követő autopszia során mintát vettünk az állatok szerveiből. Ezt követően össz-RNS-t izoláltunk, majd kvantitatív RT-PCR segítségével meghatároztuk a metilációs mintázat kialakításában fontos szerepet játszó enzimek expresszióját mRNS-szinten.

DNS-hipermetiláció és -hipometiláció is érintheti a génexpressziót, valamint a karcinogenezis többlépcsős 
folyamatát. Az epigenetikus változások célzott étrendi intervencióval visszafordíthatók lehetnek.

Nem találtunk arra vonatkozó adatot, hogy a nátriumglutamát hogyan változtatja meg a DNS-metil-transzferázok génexpressziós mintázatát sem sejtvonalon végzett, sem állatkísérletes tesztrendszerben.

Több tanulmány bizonyítja, hogy a zöld tea bioaktív vegyületei, mint például az epigallo-katekin-gallát (EGCG) megváltoztatja a DNS-metil-transzferázok aktivitását nyelőcső-, száj-, bőr-, tüdő-, mell- és prosztatatumorsejtekben egyaránt [20]. Állatkísérletekben kimutatható volt az epigallo-katekin-gallát DNS-metilációt gátló hatása $[21,22]$. Az EGCG potenciális mechanizmusát a DNMT1-gátlásra Lee és mtsai vizsgálták [23], míg Ming Zhu Fang és mtsai tanulmánya szintén bizonyítja, hogy a tea fó bioaktív komponense (EGCG) gátolja a DNMT-k aktivitását és reaktiválja a metilációt csendesítő géneket [24]. Munawwar Ali Khan és mtsai molekuláris modellezéssel vizsgálták az epigallo-katekingallát és DNMT3b, illetve HDAC1 kötődési kölcsönhatását. Megfigyelték a DNS-metil-transzferázok és hiszton-deacetilázok gátlását, RT-PCR-rel értékelték a DNMT3b és a HDAC1 transzkripciós szintjét is [25].

Shabana Majid és mtsai a bioflavonoidok közül a genisztein kemopreventív hatását vizsgálták prosztatadaganat- és egészséges sejtvonalon. A kísérlet eredményeképpen a daganatszövetben és -sejtekben a BTG3 mRNS-expressziója alulszabályozott volt. A genisztein és az 5Aza-C az összes daganatos sejtben BTG3-mRNSexpressziót indukált. A genisztein- és 5Aza-C-kezelés szignifikánsan csökkentette a promoter metilációt, újraaktiválva a BTG3-expressziót, valamint növelte a hiszton-acetiláz-3, hiszton-acetiláz-4, 2H3K4, 3H3K4 és Pol II, továbbá csökkentette a $D N M T, M B D 2$ aktivitását [26].

Priyadarsini és mtsai a kvercetin kemopreventív hatását vizsgálták 7,12-dimetil-benzantracénnel (DMBA) indukált rágcsáló buccalis zacskódaganata esetén. Immunhisztokémiával, western blottal és RT-PCR segítségével különböző markereket elemeztek, köztük az epigenetikai markereket is (HDAC1, DNMT1). A kvercetin egyidejű adásával a DMBA-val festett hörcsögöknél a daganat-előfordulás esélye csökkent, míg az kvercetinnel való utólagos kezelés hatására szignifikánsan késleltette a tumor növekedését, ráadásul sejtciklusmegállást, apoptózist, blokkolt inváziót és angiogenezist eredményezett. További eredményként pozitív korrelációt találtak a kvercetin antikarcinogén tulajdonságának köszönhető $H D A C l$ és a DNMTl gátlása között [27].

Huang és munkatársai állatkísérletben modellezték a fekete málna preventív tulajdonságát NMBA-val indukált aberrált nyelőcsőlaphámrák esetén. A fekete málna csökkentette a DNS-metil-transzferázok közül a DNMTI és DNMT3b szintjét [28].

Jiang és mtsai állatkísérletben vizsgálták a kurkumin tüdődaganatra kifejtett pozitív hatását. Tüdődaganatos sejtekben mRNS- és fehérjeszinteken a kurkumin szigni- fikánsan megemelte a RAR- $\beta$-expressziót, továbbá csökkentette a RAR- $\beta$ promoter metilációt. A vizsgálat megmutatta, hogy a kurkumin a kontrollcsoport állataihoz viszonyítva csökkenti a DNMT3b-mRNS-szinteket. Tüdődaganatos rágcsálómodellekben a kurkuminkezelés során csökkent a daganatnövekedés további lehetősége [29].

Eredményeink szerint a nátrium-glutamát mRNSszinten visszaszorította a kísérleti egerek több szervében is a DNMTI és DNMT3a génexpresszióját, hasonlóan a kemopreventív tulajdonságokkal rendelkező, epigallokatekin-galláthoz, kurkuminhez, geniszteinhez, likopinhoz, rezveratrolhoz [30-33]. Ezen vegyületekről irodalmi adatok alapján ismert, hogy képesek beavatkozni a többlépcsős karcinogenezis folyamatába, ezzel megakadályozva, késleltetve a tumorgenezist [34].

\section{Következtetések}

Kísérleti eredményeink azt mutatják, hogy a nátriumglutamát a vizsgált rendszerben nem emeli meg a daganatkialakulás kockázatát, sőt az is elképzelhető, hogy antikarcinogén hatással bír. Ugyanakkor további vizsgálatok szükségesek annak eldöntésére, hogy a nátriumglutamát kemopreventív ágensnek tekinthető-e vagy esetleg más, a karcinogenezisben szerepet játszó gének expressziójára hatással van.

Anyagi támogatás: A közlemény megírása, illetve a kapcsolódó kutatómunka anyagi támogatásban nem részesült.

Szerzői munkamegosztás: J. J. V., G. K. A., V. T., R. L. B.: A vizsgálat tervezése és lefolytatása. J. J. V., G. K. A., V. T., R. L. B.: Irodalomkutatás. R. L. B., V. T.: Statisztikai elemzések: J. J. V., V. V., Sz. Z.: Eredmények interpretációja. J. J. V., R. L. B., Sz. Z., V. V.: A kézirat megszövegezése. A cikk végleges változatát valamennyi szerző elolvasta és jóváhagyta.

Érdekeltségek: A szerzőknek nincsenek érdekeltségeik.

\section{Köszönetnyilvánítás}

Köszönjük Herczeg Mónikának és Brunnerné Bayer Zsuzsannának, a PTE ÁOK Orvosi Népegészségtani Intézet dolgozóinak, hogy segítették a munkánkat.

\section{Irodalom}

[1] The European Food Information Council: Food additives. June 2006. Available from: http://www.eufic.org/article/en/expid/ basics-food-additives/

[2] El-Wahab, H. M., Moram, G. S.: Toxic effects of some synthetic food colorants and/or flavor additives on male rats. Toxicol. Ind. Health, 2013, 29(2), 224-232. 
[3] Tsuda, S., Murakami, M., Matsusaka, N., et al.: DNA damage induced by red food dyes orally administered to pregnant and male mice. Toxicol. Sci., 2001, 61(1), 92-99.

[4] Shah, K. H., Verma, R. J.: Butyl p-hydroxybenzoic acid induces oxidative stress in mice liver - an in vivo study. Acta Pol. Pharm., $2011,68(6), 875-879$.

[5] Eweka, A. O., Igbigbi, P. S., Ucheya, R. E.: Histochemical studies of the effects of monosodium glutamate on the liver of adult wistar rats. Ann. Med. Health Sci. Res., 2011, 1(1), 21-29.

[6] Özen, H., Kamber, U., Karaman, M., et al.: Histopathologic, biochemical and genotoxic investigations on chronic sodium nitrite toxicity in mice. Exp. Toxicol. Pathol., 2014, 66(8), 367375 .

[7] Sasaki, Y. F., Kawaguchi, S., Kamaya, A., et al.: The comet assay with 8 mouse organs: results with 39 currently used food additives. Mutat. Res., 2002, 519(1-2), 103-119.

[8] Msagati, T. A.: The chemistry of food additives and preservatives. Wiley-Blackwell, 2012

[9] U.S. National Library of Medicine, Toxicology Data Network: Monosodium glutamate. Available from: http://toxnet.nlm. nih.gov/cgi-bin/sis/search2/f?./temp/ gHuJe7:3

[10] Walker, R., Lupien, J. R.: The safety evaluation of monosodium glutamate. J. Nutr., 2000, 130(4 Suppl.), 1049S-1052S.

[11] Bird, A.: DNA methylation patterns and epigenetic memory. Genes Dev., 2002, 16(1), 6-21.

[12] Okano, M., Bell, D. W., Haber, D. A., et al.: DNA methyltransferases Dnmt3a and Dnmt3b are essential for de novo methylation and mammalian. Cell, 1999, 99(3), 247-257.

[13] Delpu, ., Cordelier, P., Cho, W. C., et al.: DNA methylation and cancer diagnosis. Int. J. Mol. Sci., 2013, 14(7), 15029-15058.

[14] Ling, Y., Sankpal, U. T., Robertson, A. K., et al.: Modification of de novo DNA methyltransferase 3a (Dnmt3a) by SUMO-1 modulates its interaction with histone deacetylases (HDACs) and its capacity to repress transcription. Nucleic Acids Res., 2004, 32(2), 598-610.

[15] Sigalotti, L., Fratta, E., Coral, S., et al.: Epigenetic drugs as pleiotropic agents in cancer treatment: Biomolecular aspects and clinical applications. J. Cell. Physiol., 2007, 212(2), 330-344.

[16] Antúnez, C. A., Taja-Chayeb, L. T., Rodriguez-Segura, M. Á., et al.: DNA methyltransferases $3 \mathrm{a}$ and $3 \mathrm{~b}$ are differentially expressed in the early stages of a rat liver carcinogenesis model. Oncol. Rep., 2014, 32(5), 2093-2103.

[17] Jones, P. A., Baylin, S. B.: The epigenomics of cancer. Cell, 2007, $128(4), 683-692$.

[18] Sharma, S., Kelly, T. K., Jones, P. A.: Epigenetics in cancer. J. Carcinog., 2010, 31(1), 27-36.

[19] Ataseven, N., Yüzbaşıoğlu, D., Keskin A. C., et al.: Genotoxicity of monosodium glutamate. Food Chem. Toxicol., 2016, 91, $8-18$.

[20] Chen, D., Milacic, V., Chen, M. S., et al.: Tea polyphenols, their biological effects and potential molecular targets. Histol. Histopathol., 2008, 23(4),487-496.
[21] Henning, S. M., Wang, P., Carpenter, C. L., et al.: Epigenetic effects of green tea polyphenols in cancer. Epigenomics, 2013, $5(6), 729-741$.

[22] Yang, C. S., Kim, S., Yang, G. Y., et al.: Inhibition of carcinogenesis by tea: bioavailability of tea polyphenols and mechanisms of actions. Proc. Soc. Exp. Biol. Med., 1999, 220(4), 213-217.

[23] Lee, W. J., Shim, J. Y., Zhu, B. T.: Mechanisms for the inhibition of DNA methyltransferases by tea catechins and bioflavonoids. Mol. Pharmacol., 2005, 68(4), 1018-1030.

[24] Fang, M. Z., Wang, Y., Ai, N., et al.: Tea polyphenol (-)-epigallocatechin-3-gallate inhibits DNA methyltransferase and reactivates methylation-silenced genes in cancer cell lines. Cancer Res., 2003, 63(22), 7563-7570.

[25] Khan, M. A., Hussain, A., Sundaram, M. K., et al.: (-)-Epigallocatechin-3-gallate reverses the expression of various tumor-suppressor genes by inhibiting DNA methyltransferases and histone deacetylases in human cervical cancer cells. Oncol. Res., 2015, 33(4), 1976-1984.

[26] Majid, S., Dar, A. A., Shahryari, V., et al.: Genistein reverses hypermethylation and induces active histone modifications in tumor suppressor gene B-cell translocation gene 3 in prostate cancer. Cancer, 2010, 116(1), 66-76.

[27] Priyadarsini, R. V., Vinothini, G., Murugan, R. S., et al.: The flavonoid quercetin modulates the hallmark capabilities of hamster buccal pouch tumors. Nutr. Cancer, 2011, 63(2), 218-226.

[28] Huang, . W. ., Gu, F., Dombkowski, A., et al.: Black raspberries demethylate Sfrp4, a WNT pathway antagonist, in rat esophageal squamous cell papilloma. Mol. Carcinog., 2016, 55(11), 18671875.

[29] Jiang, A., Wang, X., Shan, X., et al.: Curcumin reactivates silenced tumor suppressor gene RAR $\beta$ by reducing DNA methylation. Phytother. Res., 2015, 29(8), 1237-1245.

[30] Link, A., Balaguer, F., Goel, A.: Cancer chemoprevention by dietary polyphenols: promising role for epigenetics. Biochem. Pharmacol., 2010, 80(12), 1771-1792.

[31] Meeran, S. M., Abmed, A., Tollefsbol, T. O.: Epigenetic targets of bioactive dietary components for cancer prevention and therapy. Clin. Epigenetics, 2010, 1(3-4), 101-116.

[32] Thakur, V. S., Deb, G., Babcook, M. A., et al.: Plant phytochemicals as epigenetic modulators: role in cancer chemoprevention. AAPSJ, 2014, 16(1), 151-163.

[33] Hardy, T. M., Tollefsbol, T. O.: Epigenetic diet: impact on the epigenome and cancer. Epigenomics, 2011, 3(4), 503-518.

[34] Li, ., Tollefsbol, T. O.: Impact on DNA methylation in cancer prevention and therapy by bioactive dietary components. Curr. Med. Chem., 2010, 17(20), 2141-2151.

(Jurasek Júlia Vanda, Putnok, Jókai Mór út 29., 3630 e-mail: jurasekjulia@gmail.com)

\section{Az Orvosi Hetilap 2017, 158, 199. oldalán (5. szám) megjelent OH-Kvízre két helyes megfejtés érkezett.}

A beküldők: Dr. Bíró László (Budapest) és Dr. Somogyi Erzsébet (Miskolc).

A nyerteseknek szívből gratulálunk.

A nyereményüket - egy, az Akadémiai Kiadó webáruházában

kedvezményes vásárlásra jogosító kupont - e-mailen küldjük el. 